\title{
Learning Lessons? The registration of lobbyists at the Scottish Parliament.
}

William Dinan is a Research Fellow at the Centre for Risk \& Governance, Glasgow Caledonian University. He is a committee member of the Association for Scottish Public Affairs has undertaken extensive research on lobbying in post devolution Scotland.

\begin{abstract}
The Scottish Parliament was founded on principles of openness and accessibility and signalled the potential for a new style of politics post devolution. In the aftermath of allegations of political sleaze early in the life of the new institution, the Standards Committee of the Scottish Parliament conducted an inquiry into the registration of lobbyists. This process attracted much comment and criticism from public affairs practitioners and the Scottish media. Based on original empirical research, numerous interviews and first hand observation, this paper offers a response to some of these criticisms and suggests the efforts by parliamentarians to regulate their relations with lobbyists need to be grounded in principles which apply to all outside interests seeking to influence the democratic process.
\end{abstract}

\section{Keywords}

Lobbying, public affairs, registration, transparency, Scottish Parliament, political communication. 


\section{Introduction}

The debate on the registration of lobbyists in Scotland has arguably failed to satisfy any of its participants or advance the understanding of contemporary lobbying in the newly devolved polity. The recent account of this process produced by Coldwell ${ }^{1}$ suggests that some lessons can be learned by public affairs practitioners, and by implication, Members of the Scottish Parliament (MSPs) regarding the embedding of lobbying around Holyrood. Coldwell offers a partial account of the Scottish Parliament's inquiry into its relations with outside interests, though he is right to emphasise the lop-sided proposals of the Standards Committee which focused the proposed register on commercial consultants only. Also, the suggestion that practitioners themselves must bear some responsibility for the negative image of lobbying in the minds of elected representatives, the media, and the general public is useful. Nevertheless, Coldwell's analysis suffers from some key omissions of detail and contestable assertions This response will attempt to clarify some of the key drivers of the debate on registering lobbyists at the Scottish Parliament and in so doing question some of the conclusions of Coldwell's analysis. In particular, the assertions that lobbying is misunderstood by elected representatives and that the lobbying industry is entirely committed to increasing transparency are challenged.

\section{Background}

Spin doctors, lobbyists and other professional communicators appear to have deep-seated image problems in the UK. It is somewhat ironic that those charged with the management of reputation should themselves be incapable of credibly defining, defending and developing their own professional image. Spin now seems to be closely connected with 
deceit, corruption, the hollowing out of democratic procedures and political disengagement. In the wake of the Hutton inquiry, where the machinations of senior government spin doctors were laid bare, the perception that democracy is being undermined by presentational politics has arguably been reinforced ${ }^{2}$. Much of the criticism of New Labour's obsession with spin and public relations has centred on the remit and activities of special advisers within government, and their relations with one set of professional communicators - political journalists and broadcasters. Less attention has been paid to the wider context where professional politics meshes with professional communicators such as lobbyists and public affairs practitioners.

In the wake of a series of political sleaze scandals in the 1990s, most famously the "cashfor-questions' affair, then Prime Minister John Major created the Committee on Standards in Public Life in 1994. Its role was to examine issues surrounding the integrity of public life in Britain, to make recommendations to ensure probity and to keep these important matters under review. A key dimension of this committee's work was to consider the relations between politicians, public servants, and civil society, including commercial interests ${ }^{3}$. The committee, initially chaired by Lord Nolan, took evidence from a range of interested parties - though with a notable bias towards 'insiders' in the Westminster political system, including lobbyists and their professional and trade associations. Eventually the committee argued for the maintenance of the British status quo whereby relations between elected representatives and outside lobbies essentially rested upon the good conduct of MPs and exhortations to best practice by lobbying associations to their members. 
An important recommendation of the Nolan report was that the registration of lobbyists would act against the accessibility of parliament by conferring special status upon accredited lobbyists. ${ }^{4}$ Such regulation could create the perception that the only legitimate route through which outside interests might engage with parliament would be via the offices of registered commercial lobbyists. This line of argument has since been repeated in a review of the Nolan report undertaken by Lord Neill ${ }^{5}$ and has come to represent official orthodoxy in relation to lobbying.

The election of New Labour in 1997 was seen by many as a chance to modernise and revitalise national politics. Elected on a reforming agenda, including an anti-sleaze platform $^{6}$ and a promise to deliver constitutional change, New Labour moved quickly to make devolution happen. Following the referendum in Scotland in September 1997 endorsing proposals for a Scottish Parliament, detailed planning for the creation of the new institution began. The model of devolution proposed for Scotland meant that key decision making powers in relation to macro-economic policy, social welfare, defence and foreign affairs, as well as broadcasting and competition were reserved to Westminster. The Scottish Parliament would take on responsibility for policy in relation to health, education, enterprise, agriculture, environment, tourism and justice. Devolution planning took place in the context of widespread cynicism regarding the discredited Westminster-style politics and the hope that Scotland, given a blank sheet, could adopt novel political practices that might help resuscitate trust in politics and promote wider civic engagement in policy making. The Scottish Office created the Consultative Steering 
Group (CSG) involving politicians and representatives of Scottish civil society, in order to develop a consensually agreed template for parliamentary procedures.

The CSG's public consultation registered disquiet about the role of lobbyists and commercial interests in contemporary public affairs. Some members of the public argued for an outright ban on lobbyists from the new Scottish Parliament while others expressed their hope that relations with outside interests would not replicate Westminster practice. Of the groups that responded to the CSG it was found that: 'Overall, most organisations were looking to see some form of regulation [of lobbying], but in as loose a form as possible so that the balance always lay in favour of organisations wishing to gain access to the Parliament'. ${ }^{7}$ The CSG settled on a familiar solution to the issue of lobbying trusting that elected members would conduct themselves properly and that lobbyists would behave with professional integrity. This faith was to be buttressed by the founding principles of the new parliament established by the CSG's consultations and deliberations. These principles decreed that the Scottish Parliament should share power with the people, be accountable and accessible, and promote equal opportunities. Notably, the strictures to accessibility suggested that the new institution should have open, transparent and responsive procedures and ought to facilitate a participative style of governance and decision making. It seemed then, that the CSG believed that were the Parliament function in an open and accessible manner there would be little need for lobbyists in Edinburgh. 
The research reported here is based upon extended fieldwork and observation of the developing lobbying industry around the new Scottish Parliament, spanning the period from late 1998 until summer 2003. It involved some seventy-three interviews with various corporate and voluntary sector lobbyists, public servants and elected representatives. It also draws upon participant observation at more than seventy official, public and private meetings for those involved in public affairs in Scotland. In addition, I also monitored the popular and specialist media in Scotland for news and analyses of issues relating to lobbying at the new Parliament, undertook focus group research to test public opinion on the issue of registration, designed and administered an e-mail survey of public servants in the U.S and Canada charged with maintaining registers of lobbyists and conducted archival research at the Scottish Executive's library at Saughton House in Edinburgh. Readers interested in more detail on the emerging lobbying industry in Scotland should consult Open Scotland? (2001). ${ }^{8}$ For a more in-depth account of the public debate on registration of lobbyists see 'Closed Scotland?' (2002). ${ }^{13}$

\section{Lobbygate and its legacy}

While the CSG were insisting that the new politics in Scotland would obviate the need for professional influence peddlers, several political consultancies were opening up for business in Edinburgh. Many were off-shoots of established PR firms, some were new entrants into the Scottish market, and others still were attached to well-established commercial law firms in Scotland ${ }^{8}$. As the Scottish Parliament opened with high expectations for democratic renewal north of the border there were mutterings in the Scottish media about low dealings within the networks surrounding New Labour in 
Scotland. Before long, the first scandal of the new politics was visited upon Holyrood in the shape of 'Lobbygate'. This involved a 'sting' by The Observer newspaper ${ }^{9}$ on Kevin Reid (son of then Secretary of State for Scotland, John Reid MP). Reid, employed as a public affairs consultant by Public Affairs Europe, a joint venture between a PR firm (Beattie Media) and a legal practice (Maclay Murray Spens), was filmed appearing to offer preferential access to senior Labour members of the new Scottish Executive, whom Reid knew personally from his time working for the party in the run up to the general election. Jack McConnell, the newly appointed finance minister in the first Scottish Executive, who had recently worked for Beattie Media setting up their lobbying business, was identified as a key conduit between Beattie Media and the Scottish political establishment.

The Standards Committee of the Scottish Parliament were under intense pressure to conduct a full public inquiry into the matters raised by The Observer due in part to the rhetoric and ideals that defined the early days of Holyrood. Critically, under the standing orders of the parliament and the committee's remit, the investigation was confined to examining the conduct of MSPs and was powerless in relation to outside interests and their behaviour. The inquiry focused on the links between Jack McConnell and Beattie Media. One lobbyist working for Beattie had claimed that he had been able to influence the ministerial diary of Jack McConnell and secure his participation at an awards dinner sponsored by a commercial client. This evidence was directly contradicted by McConnell's constituency secretary, who had also previously worked for Beattie Media. Given the inconsistencies in key evidence the inquiry concluded: 
The Committee is concerned by this conflict in the evidence ... [and] is of the view that it has the power only to rule on the conduct of MSPs and that it is not in the remit of the Committee to pursue this matter further. .... In the absence of any other evidence of engagements being arranged by Beattie Media, the Committee has concluded that there is no evidence of any undue influence over $\mathrm{Mr}$ McConnell's engagements on the part of Beattie Media. The Committee is also satisfied, on the basis of the evidence placed before it, that there has been no breach of any relevant code on the part of Mr McConnell. ${ }^{10}$

This formulation is significant as it does not 'fully exonerate' McConnell, but enters the crucial caveat that its decision was based on available evidence. The committee clearly signalled that they did not believe they had access to all the necessary evidence. Conventional wisdom in Edinburgh now suggests that 'Lobbygate' was a big fuss about very little, that McConnell was innocent of the published allegations and that the Standards Committee embarked on a crusade to register lobbyists based on a false 'perception' of the realities of lobbying in Scotland.

However, it is clear that the Standards Committee decided to investigate relations between MSPs and outside interests based on an actual conflict of evidence. Their collective dissatisfaction with their experiences during the Lobbygate hearings led many to conclude that self-regulation by lobbyists patently failed to ensure acceptable ethical practice on the part of all lobbyists. The fear within the parliament was that this situation 
- a replication of the Westminster status quo - would undermine the reputation of the fledgling institution. In the light of the evidence heard and seen by the Standards Committee there was little option but to investigate how lobbyists were interacting with the new parliament.

The notion that sleaze in Scottish politics was simply imagined by naive politicians and headline hungry journalists does not tally with events. Equally, it can be argued that the new parliament was correct in recognising that it would require some principles and procedures to handle its relations with outside interests, yet lobbyists continue to insist that the MSPs code of conduct is the only legitimate means for parliament to safeguard its standards. In the wake of Lobbygate it is therefore hardly surprising that the committee sought to generate more evidence on which to base its policy.

\section{Registering outside interests: A lobbyist's a lobbyist for a'that}

The inquiry into the registration of lobbyists at Holyrood has comprised three distinct phases. The first stage involved a survey of members experiences of lobbying which showed considerable levels of lobbying by a variety of organised groups such as trade associations, charities, unions and professional bodies. This survey detected little support for regulating lobbyists. It is slightly misleading to assert that the parliament's 'own research indicated that less than half of MSPs had ever been lobbied by a commercial lobbyist ${ }^{1}$. In fact only 47 MSPs responded to the committee's survey, and these responses were based on less than a full years experience in the parliament. It is now widely accepted that there is constant lobbying activity at Holyrood, by both commercial and 
non-commercial interests. The next phase of the inquiry extended the trawl for evidence to interested bodies and individuals in Scottish public life. The committee issued a written consultation in October 2000 and then invited oral evidence from selected respondents. The written phase of the consultation sought to gauge the experiences of lobbyists in their interaction with the parliament and test opinion on the issue of regulating lobbying. The respondents to this consultation were mainly Holyrood insiders, those professionally engaged in lobbying parliament who, unsurprisingly, were satisfied with the status quo.

A key issue throughout the consultation was the definition of lobbying proposed by the committee. In seeking to capture the range of lobbyist activity the standards committee initially proposed that lobbying be defined as 'the representation of organised interests to MSPs by the interested parties themselves, or the professional representation of organised interests by a third party, with the intention of influencing the action of MSPs'. ${ }^{11}$ The committee were repeatedly criticised for misunderstanding the nature of contemporary lobbying. Coldwell asserts that they operate with an outmoded Americanised notion of lobbying, which centres on direct interaction with elected representatives. Yet when the Standards Committee expanded their definition to include the provision of information, strategic advice and political intelligence they were criticised for (mis)using the term lobbying to describe such activities.

This of course is part of a wider definitional struggle by the British lobbying industry to disassociate themselves from the negative connotations of the term lobbyist. Lobbyists, 
including those in the voluntary sector, prefer descriptors such as public policy or public affairs advisers, political and government relations consultants, corporate communication strategists and other combinations of titles in the new lobbying lexicon that notably exclude the word lobbyist. Arguably the Standards Committee are to be congratulated for not giving in to the semantic sensitivities of the lobbying industry. The committee were trying to get clarity and transparency into public debate on lobbying in Scotland, an objective not easily advanced by indulging the labelling concerns of commercial and other lobbyists. That politicians, civil servants, journalists and others in Scottish public life seem to be comfortable with the label lobbyists should perhaps instruct lobbyists that it is time to see themselves as others see them. This perhaps is a lesson commercial lobbyists, like Coldwell, will be forced to learn. To paraphrase J.K. Galbraith, suspicions are aroused when those who are most patently lobbyists are at such pains to deny it $^{12}$. Whether lobbyists engage in direct advocacy, provide advice or background information isn't really the point. What many lobbyists singularly fail to address, amid their complaints about being misunderstood, is the nature of their political communications with clients. If the ultimate intention is to further the interests of their clients or employers, to influence MSPs and public officials, or even to gather political intelligence, then these communications should be understood as lobbying.

The written evidence to the Standards Committee inquiry from most parties confirmed that lobbyists devote much of their time and effort monitoring political developments, gathering political intelligence and - for commercial lobbyists - providing advice to clients. Most respondents were against the idea of regulation. The Committee quickly 
came to the view that commercial lobbyists posed the greatest challenge to MSPs in determining who was working on behalf of which interests, given the fact that commercial lobbyists are employed by a multiplicity of clients. MSPs were confident that they understood the terms of their interactions with in-house lobbyists (from both public and private sectors) but worried that they may be compromised in their dealings with commercial consultants. The wider issue of the transparency of lobbying processes at Holyrood to the Scottish public, who notionally are sovereign under the parliaments founding principles, did not appear to impinge upon the Committees deliberations.

The consultation process then moved to oral evidence and six groups were invited before the committee ${ }^{13}$. Much of the oral evidence amounted to a repetition of the written submissions of the various bodies. The Stirling Media Research Institute (SMRI) evidence did include some original opinion research among ordinary Scots that reaffirmed the findings of previous studies which detected low levels of trust in politicians, lobbyists and support for registration of lobbyists. This evidence also contained responses to a survey of state officials responsible for maintaining registers of lobbyists in the United States and Canada which revealed that registration schemes did not impose a barrier to political participation on the part of outside interests, including small and resource poor groups. This contrasted with the repeated assertions by nearly all those offering their opinions that a register would ultimately deter weak and marginal groups from approaching parliament. The SMRI recommended that both MSPs and all lobbyists - commercial consultants, in-house practitioners in the public, private and voluntary sectors - should be regulated in the interests of fairness and in order to secure 
the openness and transparency of the political process in Scotland in a tangible and meaningful way. This prescription was not supported by any other body giving evidence.

Those groups presenting evidence on behalf of voluntary and public sector organisations all similarly opposed registration because it would, in their opinions, act against the accessibility of Holyrood. However, both the Scottish Civic Forum and the Scottish Trades Union Council were prepared to countenance an exception to the Nolan / Neill doctrine in respect of commercial consultants. Extending this position to all lobbyists was not seen as necessary or desirable. The disposition of the committee changed perceptibly when those representing political consultants gave evidence.

Both the Association for Scottish Public Affairs (ASPA) and the Association of Professional Political Consultants Scotland (APPCS) were invited to represent the views of commercial lobbying consultants. These organisations, and the Institute of Public Relations (IPR) and the Public Relations Consultants Association (PRCA) in Scotland, had co-ordinated their written and oral responses to the inquiry in order to present a credible and unified industry voice from the very beginning of the process. ${ }^{14}$ Bringing their collective PR expertise to bear ASPA and the APPCS held a preparatory question and answer session where lawyers from a public affairs legal firm coached the lobbyists lobby. These efforts signify a couple of important points: firstly, that the industry collectively took the Committee's inquiry very seriously, and; secondly, that the industry's spokespersons were uncomfortable with the scrutiny and critical publicity that the inquiry represented. 
Despite these preparations the evidence sessions went badly for the commercial lobbyists. Neither organisation was able to provide comfort to MSPs concerned about those lobbyists operating outwith voluntary codes of conduct. The Committee were critical of ASPA for failing to regulate Beattie Media (then ASPA members) and thereby allowing the Lobbygate saga to unfold. When challenged about the raison d'etre for ASPA, Alan Boyd (the organisations first convenor and a past president of the Law Society of Scotland) denied that the organisation was set up to stymie registration, despite minutes from an early ASPA meeting recording Boyd's declaration that 'We can allow the Parliament to regulate our own affairs [or] we can get our act together and write a code which will allow us to regulate on our own'. 813

Under tough questioning from MSPs industry unity dissolved as APPCS representatives distanced themselves from ASPA. Nevertheless, they also struggled to explain aspects of their policy on regulation, particularly the fact that the APPC gave evidence to the Nolan committee endorsing a register for lobbyists - a position they were now arguing against. Before the Standards Committee APPCS gave evidence that experience around the world suggested that registration did not work, though in conversation with the author afterwards it was admitted that this information was partial and contestable.

In the wake of this round of evidence the issue of registering lobbyists was narrowed by the Committee to include only commercial consultants. Whether for practical reasons (that this group was easy to identify and had not convinced the committee in either 
written or oral evidence), political reasons (that registering commercial lobbyists was all that would likely pass a vote in the chamber) or other considerations (such as not wishing to include in-house and voluntary lobbyists, who work on behalf of some of the most powerful interests in Scotland) remains a moot point. What is clear is that this decision was not taken on the basis of any absolute principle. It is equally difficult to blame the trajectory of the inquiry on misguided MSPs, given the range of evidence supplied by various stakeholders. Essentially the process appears to have been inspired by Lobbygate, but steered by the evidence submitted and its evaluation by MSPs and their officials.

The third phase of the lobbying inquiry sought stakeholder views on what information a register of commercial lobbyists should hold. At this point many lobbyists sought to revisit the earlier debate on the principle of registration, hoping to reverse the Committees renewed determination to depart from the Westminster model and introduce some from of registration. As the inquiry neared its completion the lobbying industry in Scotland began to raise the profile of the issue in an attempt to pressurise the Standards Committee into a climb-down over its proposals ${ }^{15}$. Coldwell suggests that the Parliament could be criticised for 'focusing unduly on regulatory schemes which gave the appearance of trying to restrict...interaction [with business and other stakeholders] ${ }^{1}$. This was certainly the impression the lobbying industry was trying to give. One such organisation was the Scottish Council for Development and Industry (SCDI), which casts itself as an economic development agency but is also a powerful lobbyist with contacts and influence throughout Scottish public life. Its own public affairs employees recognise their function as lobbyists (interview with author, July 2001), though they did not admit 
to such in their late intervention in the Standards Committee inquiry, which attracted considerable publicity and increased the pressure on the Committee to revise its proposals $^{13}$.

With mounting media criticism the Committee sought to demonstrate that their plans would not restrict access to Holyrood, but were intended to make this process more open, in line with the founding principles of the parliament. Two key lines of attack were apparent in the opposition to the proposed register. The first centred on the human rights of corporations. It was argued that revealing details of a lobbyists work for clients would violate their right to privacy, as established under the European Convention on Human Rights (ECHR). Such an interpretation of the provisions of the ECHR is certainly disputable, and the Scottish Human Rights Centre suggested that the proposed register could be argued to be in the national interest, which supersedes private commercial interests. Another dimension of the proposed register was that it could include information on the clients of lobbyists and lawyers working in public affairs. This proposal was also strongly resisted, despite the reassurance that the register would not contain data on the content of information exchanged between lobbyist and client (though details on the fees being paid to lobbyists were an option being considered by the committee).

A second feature of the campaign against the register played to a wider criticism of the Parliament, namely that it is an anti-business institution that does not understand the realities of contemporary capitalism. The Scottish Parliament is sensitive to such 
criticisms, and its official embrace of the Scottish Parliament Business Exchange (SPBE) needs to be understood in this context. A subtext of the anti-business critique of the proposed register was that lobbyists understood registration as bad for their own businesses. In the aftermath of Lobbygate several commercial consultants reported that potential clients were wary of employing lobbyists and that it took some time for business to recover (though others reported to the author that mature clients understood the value of lobbying and were happy to retain their services). Perhaps this dynamic best explains the inability of most lobbyists to countenance any potential democratic benefits arising from registration.

When the Committee deliberated on the detail of a register in late 2001 the resolve to create a new framework for interacting with commercial lobbyists weakened. The issues paper that committee clerks produced was rather cautious, and highlighted the potential difficulties and labour involved in securing primary legislative force to underpin a register. As the provisions of the register were whittled down to include only the names of lobbying firms, of lobbyists employed, and who they acted for, one MSP remarked: 'I do not want to be too pejorative, but if the information [on fees, expenditures, contact programmes]... is not registered, the register will become less meaningful than we intended it to be'. ${ }^{16}$ The Committee finally endorsed a minimalist register with the sanction that those who failed to comply would be 'named and shamed'. Commercial lobbyists were happy to accept this given the information disclosure regime the Committee originally had in mind. The Committee pledged to monitor the efficacy of the 
register, though experience since then indicates this was more a token gesture than a credible threat to ensure compliance and probity.

\section{Conclusions: a new politics?}

Since the Standards Committee agreed to adopt a register of commercial lobbyists little has happened to make this a reality. In the meantime there has been renewed controversy over the role of in-house lobbyists accessing Holyrood through the SPBE scheme, the precise blind-spot of the intended register that critics identified during the registration inquiry. Nevertheless, in agreeing their work programme for the second Scottish parliament in 2003 the Committee have chosen to progress other matters. The absence of a register has dismayed and disappointed the two past convenors of the committee ${ }^{17}$.

Coldwell wonders what messages registration sends out? Given current (non) developments perhaps it is more appropriate to ask what signals the paralysis of the Committee sends to the wider Scottish public. Coldwell asserts that the inquiry 'gives the wrong message to those sceptical about the value of engaging with the parliament'. ${ }^{1}$ I think he means by this that the business community in Scotland would have a reflex hostility to registration. However, one could equally interpret such a statement to mean that public suspicion of the capture of institutional politics by organised interests groups is unlikely to be reversed by a Parliament that fails to take any meaningful initiatives to address this problem. This of course was one of the features of devolution that was heavily promoted by all those backing the project in the late $1990 \mathrm{~s}$. 
In addition, Coldwell's analysis tends to see international comparisons as problematic, especially when they take a one-dimensional view of lobbying as direct advocacy. There is little acknowledgement that Holyrood could be well served by looking to international best practice in respect of registration, freedom of information and transparency. Undoubtedly, British political culture is infused with secrecy and the conventions of clubable gentlemen - yet whether such a system is in the public interest is an issue that the lobbying industry completely ignores. In the context of increasing disengagement, and cynicism with the political process it is perhaps time that lobbyists' face up to their responsibilities to society rather than just to their clients. The recent judgement by the Parliamentary ombudsman that contacts between 10 Downing Street and commercial interests should be a matter of public record ${ }^{18}$ indicates that concerns about the probity of public life are unlikely to disappear, and that concrete measures are needed to make decision making processes more transparent.

Instead of advancing spurious arguments that equate lobbyists' representations on behalf of transnational corporations with the rights to petition by private citizens enshrined in British politics since the Magna Carta, the public affairs industry should recognise that they are currently part of the problem. In helping to advance the openness and transparency of the political process by cooperating with registration they might become part of a solution. The reaction of the lobbying industry to registration can be seen as an objection to proposals that would be bad for their own interests in the short run, though potentially positive for democracy (and interest representation) in the long run. 
Advocating 'symmetrical two-way communication' as a solution to the current participatory malaise in our democracy is a rather feeble and empty notion, especially given the chronic lack of good faith displayed by the Scottish lobbying industry throughout the Committee's inquiry. The disparities between what many lobbyists said in public and private suggests there is little scope for mutual understanding ${ }^{813}$. Finally, the recommendation that lobbyists more readily acknowledge where they have 'added value' in the political process is very puzzling, given that this was the whole point of a transparent registration scheme, aimed at opening up decision making and influence to scrutiny. Lobbyists have repeatedly indicated that they are unwilling to do this on anything but their own terms (such as in a pitch for new business?) and therefore the public remain sceptical that the value added by lobbyists is largely on behalf of private interests. This scepticism is likely to be reinforced when the next lobbying scandal is exposed in the media, and elected representatives are prompted to again try to resolve their relations with outside interests. If any lessons are to be learned they might be that such efforts are best guided by sound democratic principles, such as those established by the CSG and indeed the Standards Committee. Related to this is the recognition that attempts to make the lobbying process more transparent will be met by fierce resistance by commercial and in-house lobbyists. The campaign waged by vested interests in Scotland against a fairly modest registration scheme intended to give substance to the principles of openness and transparency is certainly instructive in this regard. This case study demonstrates the difficulty of translating principles into practice. It also points to the deeply ingrained pro-business assumptions and aversion to public scrutiny in British political culture. A critical weakness of the lobbyist registration scheme in Scotland was 
that it sought to target only one group of lobbyists - the commercial consultants. Some insiders thought that this was at the limits of what might be politically acceptable to the Parliament. However the key lesson to be taken from this episode is that any proposed reforms or solutions to the problematic relationship between elected representatives, officials and outside interests should apply to all interests equally.

\footnotetext{
${ }^{1}$ Coldwell, I. (2002) 'The registration of lobbyists in the Scottish Parliament: The lessons for communications professionals', Journal of Communication Management, Vol. 8, 1, 95 - 100.

${ }^{2}$ See 'Standards Check' p11, Committee on Standards in Public Life, annual report 2003. http://www.public-standards.gov.uk/annual_reports/2003/2003.pdf. Also, see opinion research commissioned by the committee, and carried out by the National Centre for Social Research http://www.natcen.ac.uk/natcen/pages/publications/conduct_in_public.pdf.
}

3 The initial terms of reference for the committee were set out as follows: "To examine current concerns about standards of conduct of all holders of public office, including arrangements relating to financial and commercial activities, and make recommendations as to any changes in present arrangements which might be required to ensure the highest standards of propriety in public life."

${ }^{4}$ Nolan Committee (1995) Standards in Public Life, vol I, Cm 2850-I, London: HMSO. http://www.archive.official-documents.co.uk/document/cm28/2850/2850.htm

${ }^{5}$ Neill Committee (2000) Reinforcing Standards: Review of the First Report of the Committee on Standards in Public Life, vol I, Cm 4557-I, London: The Stationary Office. http://www.archive.official-documents.co.uk/document/cm45/4557/4557.htm

${ }^{6}$ Gould, P. (1998) The Unfinished Revolution: How the Modernisers Saved the Labour Party, Abacus: London. Chapter 10.

${ }^{7}$ Scottish Office (1998) Report of the Consultative Steering Group on the Scottish Parliament. See Annex D for analysis of consultation responses. http://www.scotland.gov.uk/library/documents-w5/rcsg-19.htm

${ }^{8}$ For a full account of the gravitation of lobbyists to Edinburgh in anticipation of devolution and the early debate on the registration of outside interests see Schlesinger, P., Miller, D. and Dinan, W. (2001) Open Scotland? Journalists, Spin Doctors and Lobbyists, Polygon: Edinburgh.

${ }^{9}$ Nelson, D. and B. Laurance (1999) 'Exposed: Lobbygate comes to Scotland', The Observer in Scotland, 26 September, p.1.

${ }^{10}$ Standards Committee (1999) Report of an inquiry into matters brought to the attention of the Committee by The Observer newspaper, First Report, SP paper 27, ST/99/R1, 18 November, paragraphs 34-35. http://www.scottish.parliament.uk/S1/official_report/cttee/stan99-00/str01-1.htm\#conclusions)

${ }^{11}$ Standards Committee (2000) Lobbying in the Scottish Parliament: Consultation Paper, SP paper 200, October. http://www.scottish.parliament.uk/S1/official_report/cttee/stan-00/st-consult-02.htm\#03.

${ }^{12}$ Galbraith, J. K. (1983) The Anatomy of Power, Corgi Books: London, p. 138.

${ }^{13}$ These included the author as a member of the Stirling Media Research Institute (SMRI), the Association of Professional Political Consultants Scotland (APPCS), the Association for Scottish Public Affairs (ASPA), the Scottish Civic Forum, the Scottish Council for Voluntary Organisations (SCVO), the 
Convention of Scottish Local Authorities (COSLA) and the Scottish Trades Union Congress (STUC). This evidence can be viewed at http://www.scottish.parliament.uk/S1/official_report/cttee/stan-01/st010301.htm and http://www.scottish.parliament.uk/S1/official_report/cttee/stan-01/st01-0401.htm

${ }^{14}$ Ian Coldwell, in his capacity as chair of the IPR in Scotland, participated in a meeting hosted by ASPA in November 2000 to rehearse the industry position on the issues raised in the consultation process. The author was also present.

${ }^{15}$ For a complementary account of the PR campaign waged by the lobbying industry in Scotland against the proposed register see Schlesinger, P., Dinan, W. and Miller, D. (2002) 'Closed Scotland? lobbying at holyrood' in Hassan, G. and Warhurst, C. (eds) Anatomy of the New Scotland: Power, Influence and Change, Edinburgh: mainstream, pp 65-74.

${ }^{16}$ http://www.scottish.parliament.uk/S1/official_report/cttee/stan-01/st01-1502.htm\#Col897. The information that was first proposed for the register included: descriptive information about the company or organization; specific information on the subject matters lobbied, for example, naming the Bill; details of expenditure in relation to individual lobbying projects; details of fees received in relation to individual lobbying projects; details of MSPs contacted; and communication techniques. All such data was dropped from the final proposals of the Committee. For the full issues paper see: http://www.scottish.parliament.uk/S1/official_report/cttee/stan-01/stp01-15.pdf

${ }^{17}$ Hutcheon, P. (2004) 'Lobbying: Members Only’ Holyrood Magazine, 23 February, p44-45.

${ }^{18} \mathrm{http} / / /$ politics.guardian.co.uk/foi/story/0,9061,1170196,00.html 